\title{
Role of Vitamin E on Indomethacin induced low pH of Seminal Fluid in Long Evans Rats
}

\author{
Md. Jahangir Alam ${ }^{1}$, Humaira Naushaba ${ }^{2}$, Uttam Kumar Paul ${ }^{3}$, Tahmina Begum $^{4}$, Sunjida \\ Shahriah $^{5}$, Md. Shameem Ahmed ${ }^{6}$, Md. Moazzem Hossain
}

\begin{abstract}
Context: Indomethacin is the most commonly and widely used nonsteroidal antinflammatory analgesic and antipyretic drug. Though it is effective drug in various diseases, indomethacin causes inhibition of spermatogenesis by lowering the $\mathrm{pH}$ of seminal fluid leading to infertility. On the other hand, vitamin $\mathrm{E}$ enhances spermatogenesis by increasing $\mathrm{pH}$ of the seminal fluid. Therefore, the present study was designed to observe the protective role of vitamin $\mathrm{E}$ on indomethacin induced low $\mathrm{pH}$ of seminal fluid in testicular damage.
\end{abstract}

Objective: To observe the effects of vitamin $\mathrm{E}$ on indomethacin induced low $\mathrm{pH}$ of seminal fluid in testicular damage in Long Evans rats.

Study design: An experimental study.

Place and period of study: The study was carried out in the Department of Anatomy, Sir Salimullah Medical College, Dhaka in the period of August, 2005 to June, 2006.

Materials and methods: Eightyfour mature Long Evans male rats were divided into four groups (I, II, III and IV). The rats of group I, II and III were treated with indomethacin at different doses and duration. Group IV rats were treated with indomethacin plus vitamin $E$ at different doses for 49 days. The $\mathrm{pH}$ of seminal fluid were measured biochemically.

Results: There was significant reduction $(P<0.001)$ of $\mathrm{pH}$ of seminal fluid when the rats were treated with indomethacin at low (2 mg/kg body weight/day) and high (10 mg/kg body weight/day) doses for 7, 14 and 42 days, respectively. On the other hand, rats treated with indomethacin plus vitamin $E$ for 49 days showed increase in $\mathrm{pH}$ of seminal fluid compared to other groups $(P<0.001)$.

Conclusion: It can be concluded from the study that vitamin $E$ has potential role in the prevention of the antispermatogenic effects of indomethacin by increasing the $\mathrm{pH}$ of seminal fluid.

Key words: seminal fluid, indomethacin, vitamin $E$

Introduction

Indomethacin is the most commonly and widely used nonsteroidal antiinflammatory (NSAID), analgesic and antipyretic drug. It was first introduced in 1963 for the treatment of rheumatoid arthritis and related disease ${ }^{1,2,3}$. Though it is an effective drug, toxic effect to testes and accessory organs have significantly restricted its use.

1. Assistant Professor of Anatomy (c.c), Sir Salimullah Medical College, Dhaka

2. Professor and Head, Department of Anatomy, Sir Salimullah Medical College, Dhaka

3. Assistant Professor (c.c), Department of Anatomy, Sir Salimullah Medical College, Dhaka

4. Lecturer, Department of Anatomy, Sir Salimullah Medical College, Dhaka

5. Assistant Professor, Department of Anatomy, Chattagram Ma-O-Shishu Hospital and Medical College, Chittagong

6. Associate Professor and Head, Department of Anatomy, Central Medical College, Comilla

7. Assistant Professor, Enam Medical College, Savar, Dhaka Correspondence: Dr. Md. Jahangir Alam

2
Prolonged treatment with indomethacin caused decrease in prostaglandin $\mathrm{E}_{2}\left(\mathrm{PGE}_{2}\right)$ level in seminal fluid by $80-90 \%$ and reduces fertility significantly by lowering the $\mathrm{pH}$ of seminal fluid in human being ${ }^{4}$. On the other hand, vitamin $E$ is a fat soluble vitamin. It enhances spermatogenesis by inhibition of lipid peroxidation and lowers the incidence of abnormal sperm production by increasing $\mathrm{pH}$ of seminal fluid ${ }^{5,6}$.

Therefore, the present study was designed to observe the protective role of vitamin $\mathrm{E}$ on indomethacin induced low $\mathrm{pH}$ of seminal fluid in testicular and accessory sex organ damages.

\section{Materials and Methods}

Eightyfour mature Long Evans male rats of 2.5 to 3.5 months old, weighing 200-300 gms were included in this study.

Drugs: The following drugs were used in the present study: 
1) Indomethacin powder: (a) Low dose $2 \mathrm{mg} / \mathrm{kg}$ body weight/day, and (b) High dose $10 \mathrm{mg} / \mathrm{kg}$ body weight/day. Indomethacin suspensions were made in distilled water and administered intragastrically ${ }^{4,7}$.

2) Vitamin $E$ powder, dose $100 \mathrm{mg} / \mathrm{kg}$ body weight/day. Suspensions of vitamin $\mathrm{E}$ were administered intragastrically ${ }^{8}$.

3) Vehicle: Distilled water for control group, dose $2 \mathrm{ml} / \mathrm{rat} /$ day.

\section{Methods}

Eightyfour male rats were divided into four main groups (I, II, III and IV). These main groups were again divided into three subgroups 'a' (control), 'b' (indomethacin $2 \mathrm{mg} / \mathrm{kg} / \mathrm{body}$ weight/day) and ' $\mathrm{c}$ ' (indomethacin $10 \mathrm{mg} / \mathrm{kg}$ body weight/day). Each subgroup included 7 rats. Grouping of animals and their treatment were done on the basis of duration of treatment ${ }^{6}$.

Rats of group I, II and III were treated by indomethacin at low and high doses for 7, 14 and 42 days, respectively. Group IV rats were treated with indomethacin low ( $2 \mathrm{mg} / \mathrm{kg}$ body weight/day) and high (10 mg/kg body weight/day) dose plus vitamin $E$ (100 mg/kg body weight/day) for 49 days.

For determination of $\mathrm{pH}$ of seminal fluid, the animals were sacrificed by cervical dislocation under ether anaesthesia?. After sacrifice, the abdomen of the rats were opened at autopsy and right seminal vesicle was taken out and used for determination of $\mathrm{pH}$ of the seminal vehicle. The right seminal vesicle was gently minced with a fine scissors. The $\mathrm{P}^{\mathrm{H}}$ indication paper (manufactured by Merck of Germany) was made wet with the extract of seminal vesicle. The $\mathrm{pH}$ was calculated by matching the colour of indicator paper with that of standard colour table ${ }^{9}$.

For statistical analysis, the data obtained from different groups of rats were analyzed and comparisons were made using unpaired Student's 't' test.

\section{Results}

There was significant reduction $(\mathrm{P}<0.001)$ in $\mathrm{pH}$ of seminal fluid when the rats were treated with indomethacin at low ( $2 \mathrm{mg} / \mathrm{kg}$ body weight/day) and high (10 mg/kg body weight/day) dose for 7, 14 and 42 days, respectively. On the other hand, rats treated with indomethacin plus vitamin $\mathrm{E}$ for 49 days showed significant increase $(\mathrm{P}<0.001)$ in $\mathrm{pH}$ of seminal fluid compared to control and other groups (Table I).
Table I

Effect of indomethacin/indomethacin plus vitamin $\mathrm{E}$ on $\mathrm{pH}$ of seminal fluid of different groups of rats

\begin{tabular}{ccc}
\hline Groups & $\begin{array}{c}\text { Duration of } \\
\text { treatment } \\
\text { (days) }\end{array}$ & $\begin{array}{c}\mathrm{pH} \text { of } \\
\text { seminal fluid } \\
\text { Mean } \pm \text { SD }\end{array}$ \\
\hline Ia & 7 & $7.59 \pm 0.13$ \\
& & $(7.4-7.8)$ \\
Ib & 7 & $7.41 \pm 0.07$ \\
& & $(7.3-7.5)$ \\
IC & 7 & $7.26 \pm 0.08$ \\
& & $(7.2-7.4)$ \\
IIa & 14 & $7.64 \pm 0.10$ \\
& & $(7.5-7.8)$ \\
IIb & 14 & $7.34 \pm 0.13$ \\
& & $(7.2-7.5)$ \\
IIc & 14 & $7.26 \pm 0.08$ \\
& & $(7.2-7.4)$ \\
IIIa & 42 & $7.63 \pm 0.10$ \\
& & $(7.5-7.8)$ \\
IIIb & 42 & $7.30 \pm 0.08$ \\
& & $(7.2-7.4)$ \\
IIIc & 42 & $7.08 \pm 0.10$ \\
& & $(7.0-7.2)$ \\
IVa & 49 & $7.53 \pm 0.11$ \\
& & $(7.47 .7)$ \\
IVb & 49 & $7.50 \pm 0.06$ \\
& & $(7.47 .6)$ \\
IVc & $4.44 \pm 0.05$ \\
& & $(7.47 .5)$
\end{tabular}




\begin{tabular}{|c|c|}
\hline Groups & Pvalue \\
\hline la vs Ib & $<0.05^{\star}$ \\
\hline la vs Ic & $<0.001^{* * *}$ \\
\hline Ib vs Ic & $<0.01^{\star \star}$ \\
\hline Ila vs Ilb & $<0.001^{* * *}$ \\
\hline Ila vs IIc & $<0.001^{* \star *}$ \\
\hline IIb vs IIc & $>0.10^{\mathrm{ns}}$ \\
\hline IIla vs IIIb & $<0.001^{\star \star \star}$ \\
\hline IIla vs IIIC & $<0.001^{* \star \star}$ \\
\hline IIIb vs IIIc & $<0.001^{\star \star \star}$ \\
\hline IVa vs IVb & $>0.50^{\mathrm{ns}}$ \\
\hline IVa vs IVc & $>0.05^{\mathrm{ns}}$ \\
\hline IVb vs IVc & $>0.05^{\mathrm{ns}}$ \\
\hline IIIb vs IVb & $<0.001^{\star \star \star}$ \\
\hline IIIc vs IVc & $<0.001^{\star \star \star}$ \\
\hline
\end{tabular}

Figures in parentheses indicate range. Comparison between groups done by Unpaired Student's 't' test,

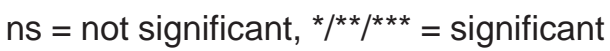

\section{Discussion}

The $\mathrm{pH}$ of the seminal fluid of all indomethacin treated rats were reduced. The reduction in $\mathrm{pH}$ of seminal fluid were highly significant $(P<0.001)$ in the rats treated with indomethacin at low and high doses for longer duration (14 and 42 days).

Similar findings were also observed by Balasubramanian et al. ${ }^{7}$, Kumar and Chinoy ${ }^{6}$, and $\mathrm{Ara}^{10}$. The reduction in $\mathrm{pH}$ may be due to the atrophy of seminal vesicle.

The $\mathrm{pH}$ of seminal fluid increased markedly $(P<0.001)$ in vitamin $E$ treated rats in comparison to control group and also to indomethacin treated group of rats. This result is similar to the results observed by Cooper and Carpenter ${ }^{8}$, Mishra and Achary $^{5}$. The increase in $\mathrm{pH}$ of seminal fluid may be due to inhibition of lipid peroxidation which enhances spermatogenesis and lowers the incidence of abnormal sperm production.

\section{References}

1. Robert LJ, Morrow JD. Analgesic antipyretics and antiinflammatory agents and drugs employed in the treatment of gout. In: Limbrid LE, Hardman JG, editors. Goodman and Gilman's: the pharmacological basis of therapeutics. 16th ed. New York: McGraw Hill Companies, 2001: p.687-731.

2. Guyton AC, Hall JE. Textbook of medical physiology. 10th ed. Philadelphia: WB Saunders Company, 2002: p.916-28.

3. Ganong WF. Review of medical physiology. 21st ed. New York: McGraw Hill Companies, 2003: p.428-37.

4. Loscher W, Blazaki D. Effect of nonsteroidal antiinflammatory drugs on fertility of male rats. J Reprod Fert 1986; 76:65- 73.

5. Mishra M, Acharya VR. Protective effect of vitamin $E$ on spermatogenesis in lead treated Swiss mice. Med J Biol Trace Elem 2004; 18;173-8.

6. Kumar RA, Chinoy NJ. Effects of acetyl salicylic acid on reproductive organs of adolescent male rats. J Endocrin Expl 1988; 22:187-95.

7. Balasubramanian A, Manimekalai S, Guna Singh A, Rama Krishnan S. Short and long term effect of aspirin on testes of albino rats. Indian J Expl Biol 1980; 18:1408-10.

8. Cooper DR, Carpenter MP. Sertoli cell prostaglandin synthesis: effects of (follitropin) differentiation and dietary vitamin E. Biochem J 1987; 241:847-55.

9. Banu MLA. Protection from cyclophosphamide induced damage of spermatogenesis in the rat by androgen [thesis]. Dhaka: University of Dhaka, 1997.

10. Ara S. Histomorphological changes in testes induced by aspirin and its prevention by prostaglandins in rat [thesis]. Dhaka: University of Dhaka, 1992. 